\title{
Variations in patterns of follicle development in prolific breeds of sheep
}

\author{
M. A. Driancourt, I. K. Gauld*, M. Terqui and R. Webb* \\ I.N.R.A., Reproductive Physiology, 37380 Nouzilly, France, and *AFRC, Institute of Animal \\ Physiology and Genetics Research, Dryden Laboratory, Roslin, Midlothian EH25 9PS, U.K.
}

\begin{abstract}
Summary. Prolific breeds of sheep (Romanov, Finn and Booroola Romanov crosses heterozygous for the Booroola gene $(\mathrm{F}+)$ were compared with breeds of lower prolificacy (Ile-de-France, Finn $\times$ Scottish Blackface, Merino $\times$ Blackface and Booroola $\times$ Romanov not carrying a copy of Booroola gene $(++)$ ) by in-vivo monitoring of follicular kinetics by ink labelling during the late luteal phase and follicular phase of the oestrous cycle followed by histological examination of the ovaries or follicle dissection. At each of 3 successive laparotomies, the 3 largest follicles of each ovary were measured and ink labelled. At the final laparotomy, around the beginning of oestrus, all ewes were ovariectomized.

High ovulation rate was not associated with the total number of antral follicles in any of the breeds. However, there were more follicles $>2 \mathrm{~mm}$ in diameter in Romanov and Booroola $\times$ Romanov crosses $(F+)$ compared to their respective controls. Such a feature was not observed in Finnish Landrace compared to Finn $\times$ Blackface and Merino $\times$ Blackface ewes. A more numerous population of recruitable follicles, together with a similar incidence of selection through atresia, were the features associated with the high ovulation rate of Romanov compared to Ile-de-France ewes. The high ovulatory potential of the Finn ewes resulted from a markedly reduced incidence of selection through atresia. Booroola $\times$ Romanov ewes carrying a copy of the Booroola gene $(\mathrm{F}+)$ appeared to possess features of both parental breeds, including high numbers of recruitable follicles, smaller follicular size when recruitment occurs and an extended time for recruitment. Booroola $\times$ Romanov $(++)$ ewes, not carrying the gene, appeared to have lost part of the 'Romanov characteristics' of a more numerous population of recruitable follicles. The variability in the kinetics of preovulatory enlargement, seen in these breeds of sheep, demonstrates that there are a number of pathways through which high ovulation rate can be achieved and hence through which ovulation rate might be manipulated.
\end{abstract}

\section{Introduction}

Ovulation rate is a major determinant of reproductive rate in mammals. There is considerable variation in ovulation rate between breeds of sheep and between strains of sheep within breeds. Despite numerous studies the exact mechanisms which control ovulation rate are still not known (see reviews by Scaramuzzi \& Radford, 1983; Webb \& Gauld, 1984; Bindon, 1984). A number of follicular characteristics have been associated with higher ovulation rate. Follicular size, together with the number of granulosa cells in preovulatory follicles is markedly reduced in the prolific Booroola Merino (Baird, Ralph, Seamark, Amato \& Bindon, 1982; Scaramuzzi \& Radford, 1983; Driancourt, Cahill \& Bindon, 1985a). Preovulatory follicles also tend to be smaller in Finnish Landrace ewes with a higher ovulation rate than in Suffolk ewes (Webb \& Gauld, 1984). However, 
this trend was not found in Romanov ewes compared with Ile-de-France ewes (Cahill \& Mauléon, 1980). Follicular response to $\mathrm{LH}$ is also acquired in smaller follicles in Booroola ewes compared to Merino ewes (Scaramuzzi, Turnbull, Downing \& Bindon, 1981). Furthermore, decreased ovarian inhibin content has been found in Booroola Merino ewes compared to the prolific T Merino and control Merino ewes (Cummins, O'Shea, Bindon, Lee \& Findlay, 1983; Bindon, 1984). These between-breed and strain differences suggest that each breed might have a different mechanism by which ovulation rate is controlled.

The technique of ink labelling of individual follicles, at successive laparotomies, has been used to study the dynamics of preovulatory follicular enlargement as it allows the monitoring of the growth and regression of individual follicles $>2 \mathrm{~mm}$ in diameter, which form the population of recruitable follicles from which the ovulatory follicles will be selected (Driancourt \& Cahill, 1984; Tsonis, Cahill, Carson \& Findlay, 1984). The aim of the present experiments was to combine ink labelling with histology to study the dynamics of preovulatory enlargement during the follicular phase of the oestrous cycle in three prolific breeds or strains of sheep (Romanov, Finnish Landrace and Booroola $\times$ Romanov ewes, heterozygous for the Booroola gene) and compare these animals with breeds having a lower prolificacy (Ile-de-France, Finnish Landrace $\times$ Scottish Blackface, Merino $\times$ Scottish Blackface and Booroola $\times$ Romanov not carrying the Booroola gene) .

\section{Materials and Methods}

\section{Animals and experimental design}

Experiment I. During the late breeding season (January), at Nouzilly, the oestrous cycle of 8 mature (2-4 years old) Romanov ewes and 8 mature (2-4 years old) Ile-de-France ewes were synchronized with fluorogestone acetate $(40 \mathrm{mg})$-impregnated sponges inserted for 14 days (Intervet, Angers, France). Ewes were tested for oestrus (Day 0) every $3 \mathrm{~h}$ for $48 \mathrm{~h}$, starting $36 \mathrm{~h}$ after sponge removal. At Day 13 after the synchronized oestrus, all ewes underwent a first laparotomy during which the 3 largest follicles of each ovary were measured and ink labelled with dots of India ink in the ovarian stroma surrounding the follicles (Driancourt \& Cahill, 1984). All ewes received $125 \mu \mathrm{g}$ cloprostenol (Estrumate: ICI, 95022 Cergy, France) on Day 14 to improve the synchrony of oestrus. At Day 15, the 3 largest follicles of each ovary were again measured and ink labelled and those previously marked also measured. At the third and final laparotomy, $7-15 \mathrm{~h}$ after the beginning of oestrus, all marked follicles were measured and all ewes then ovariectomized. Driancourt (1985) has shown that mean deviation of the size measured on the ovarian surface in relation to the actual size after dissection does not exceed $10 \%$, and so the accuracy of measurements for growing follicles $>2.5 \mathrm{~mm}$ in diameter is good. Enlarging follicles between successive laparotomies were assumed to be healthy while regressing ones were assumed to be atretic.

Experiment II. Nine adult (2 years old) Booroola Merino $\times$ Romanov ewes born from a single ram, were used in this experiment. Results of progeny testing indicated that the Booroola Merino ram, imported from CSIRO Armidale, Australia, in 1981 and used to sire Romanov ewes, was heterozygous for the Booroola gene (R. Ortavant, personal communication). Due to the fact that the breed used in the crossing scheme was the Romanov instead of the Merino, assignment of the ewes to carriers $(\mathrm{F}+)$ or non-carriers $(++)$ could not be carried out using the usual criteria (Davis, Montgomery, Allison \& Kelly, 1982). Therefore ewes were assessed as carriers if they had a minimum ovulation rate of 3 and had exhibited at least once an ovulation rate of 4 . In contrası non-carriers had mostly twin ovulations and never 4 ovulations. Laparoscopic examinations performed in these ewes between 5 and 16 months of age showed that 5 ewes were carriers and 3 ewes were non-carriers. Only a single record of 3 was available to rank the remaining ewe. During the mid-breeding season (November) oestrus in all ewes was synchronized with fluorogestone acetate and the ewes were studied during the next cycle. The experimental design was exactly as described for Exp. I. 
Experiment III. During the mid-breeding season (November) oestrous cycles of 12 Finnish Landrace, 16 Finn $\times$ Scottish Blackface and 16 Merino $\times$ Blackface ewes $($ ABRO, Roslin) were synchronized with a 12-day treatment with progestagen-impregnated sponges (MAP: Intervet). After sponge removal, ewes were checked twice daily for heat. Within each breed ewes were randomly allocated to two groups; those in Group I (6-8 ewes of each breed) underwent the first laparotomy for measurement and ink labelling of the 3 largest follicles on each ovary on Day 9. Ewes were injected with $125 \mu \mathrm{g}$ cloprostenol at $21: 00 \mathrm{~h}$ on Day 10 and then underwent laparotomy, again for follicular measurements and ovariectomy, on Day 11. Group II ewes (6-8 of each breed) underwent laparotomy and ink labelling of the 3 largest follicles on Day 9 of the cycle. The ewes were injected with cloprostenol at 21:00 h on Day 10 and then, on Day 11, underwent laparotomy for the second time, together with ink labelling of any of the 3 largest follicles of each ovary not previously marked and follicular measurements of all marked follicles. The ewes were ovariectomized on Day 12 ( 2 days after cloprostenol treatment) when all the labelled follicles were again measured.

\section{Histological techniques and follicle classification}

After ovariectomy, the ovaries of Romanov and Ile-de-France ewes (Exp. I) and Booroola $\times$ Romanov crosses (Exp. II) were fixed in Bouin-Hollande's solution and serially sectioned at a thickness of $10 \mu \mathrm{m}$. One section out of 6 was mounted and the slides were stained with haematoxylin.

Antral follicles (possessing an antrum $>1000 \mu \mathrm{m}^{2}$ ) were counted and measured using the oocyte as a marker. The area of all the follicles was measured in $\mu \mathrm{m}^{2}$ and then converted to $\mathrm{mm}$, assuming that the follicle was spherical. The follicles were then ranked in 5 size classes as previously defined (Driancourt \& Mariana, 1982), each of them coinciding with one of the main events of follicular growth: Class $1(0.20-0.32 \mathrm{~mm}$ diam.), appearance of the antrum; Class $2(0.32-0.50 \mathrm{~mm}$ diam.), increase in the mitotic index of the granulosa cells; Class $3(0.50-0.80 \mathrm{~mm}$ diam.), appearance of atresia; Class 4 (0.80-2.0 mm diam.), maximum values in the mitotic index of the granulosa cells; Class 5 ( $>2 \mathrm{~mm}$ diam.), final differentiation of follicles that will undergo preovulatory maturation. All follicles were also classified as normal or atretic. An atretic follicle was defined as a follicle with $>5$ pycnotic bodies in the granulosa layer of the section studied. Included in this class of atretic follicles were follicles with widespread disintegration of the granulosa cells, but still containing an oocyte. Follicles in very late atresia, in which no oocyte could be found were not considered in this study. Large healthy follicles, from ewes ovariectomized after showing oestrus, were identified as the putative preovulatory follicles. Because the oocyte is not always located in the centre of the follicle (Driancourt et al., 1985a), to estimate accurately the number of granulosa cells in a sample of preovulatory follicles, the diameter, thickness and number of granulosa cells were measured in the histological section with the largest diameter and calculations made according to Pedersen (1970) and Gougeon (1981). After ovariectomy, the ovaries of the Finn, Finn $\times$ Blackface and Merino $\times$ Blackface ewes were carefully dissected and all follicles $>2 \mathrm{~mm}$ in diameter were measured.

\section{Statistical methods}

Due to the lack of normal distributions, non-parametric testing was used to compare the means including the Mann-Whitney $U$ test and/or the Kruskal-Wallis one-way analysis of variance. Spearman rank correlations were used to estimate the relationships between parameters (Siegel, 1956). Distributions were compared by 2I tests (Sokal \& Rohlf, 1969). All results are expressed as means \pm s.d. 


\section{Results}

\section{Ovulation rate and number of preovulatory follicles}

In Exp. I, the mean ovulation rates, calculated from the number of corpora lutea of the previous cycle, were $3.5 \pm 0.7$ and $1 \cdot 1 \pm 0.3$ for Romanov and Ile-de-France ewes respectively. In Exp. II, the 3 Booroola $\times$ Romanov ewes without the gene $(++)$ had a mean ovulation rate of $2 \cdot 0 \pm 0 \cdot 0$, while the 5 Booroola $\times$ Romanov heterozygous ewes $(F+)$ had a mean ovulation rate of $4.6 \pm 0 \cdot 8$. On the basis of the number of corpora lutea found at the first laparotomy (i.e. 2) it was decided to rank the previously undefined remaining ewe to the $(++)$ group. This was further supported by the finding at the end of the experiment that this animal had only a single preovulatory follicle. In Exp. III, the ovulation rates were $3.25 \pm 0.8,2.4 \pm 0.7$ and $1.4 \pm 0.5$ for Finn, Finn $\times$ Blackface and Merino $\times$ Blackface ewes respectively.

In all the experiments, the number of presumptive preovulatory follicles was similar to the ovulation rate, the difference never exceeding one. This suggests that the experimental procedures did not upset the physiological mechanisms contributing to terminal follicular growth. This further confirmed the ranking of the Booroola $\times$ Romanov ewes as carriers $(F+)$ (number of preovulatory follicles $5 \cdot 0 \pm 1 \cdot 2$ ) and non-carriers $(++)$ (numbers of preovulatory follicles $1 \cdot 7 \pm 0 \cdot 5$ ).

\section{Experiment I}

There was no significant difference between the breeds in the follicle size at which an antrum was first detected. Histological examination of the ovaries showed that the population of antral follicles in the two breeds was not significantly different, being $67.4 \pm 29.6$ and $59.5 \pm 19.9$ for Romanov and Ile-de-France ewes respectively. A feature common to the two breeds was the high withinbreed variability. The number of antral follicles per ewe ranged from 22 to 103 in Romanov ewes and from 25 to 78 for Ile-de-France ewes (Fig. 1). Despite the similarity in the number of antral follicles, the size distribution differed significantly between breeds $(P<0.05)$. Ovaries of Romanov ewes contained more follicles in Classes $1(22.2 \pm 13.9$ versus $6.2 \pm 5.2 ; P<0.01)$ and $5(3.5 \pm 1.8$

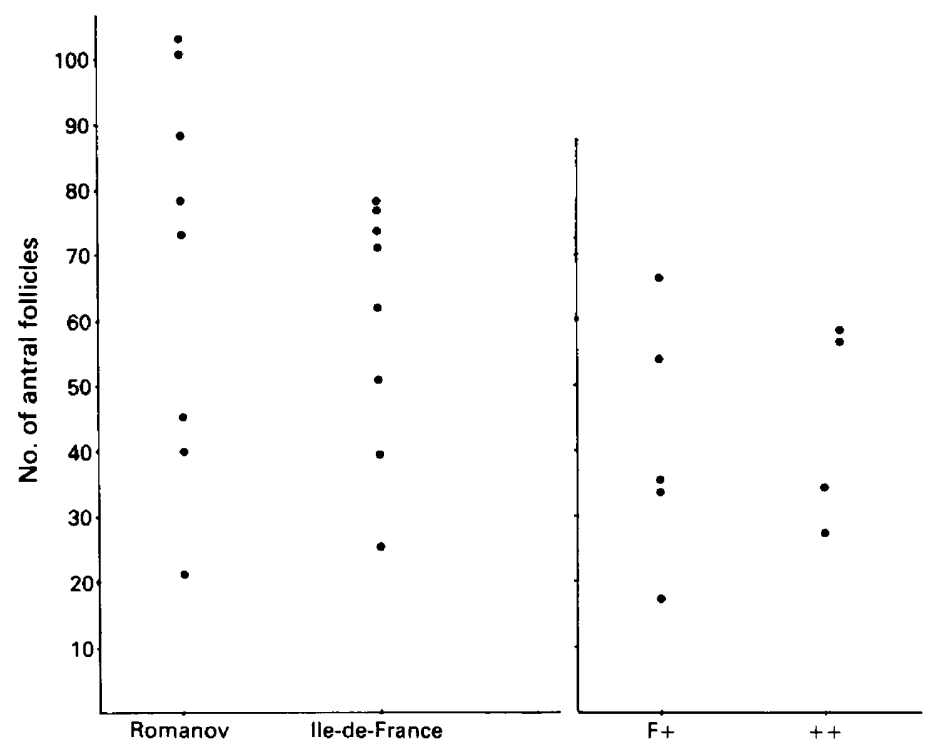

Fig. 1. Numbers of antral follicles per ovary in Romanov and Ile-de-France ewes (Exp. I) and in F + and ++ Booroola $\times$ Romanov ewes (Exp. II). 
versus $1.2 \pm 0.8 ; P<0.01)$, but fewer in Class $4(15.7 \pm 6.1$ versus $28.2 \pm 8.6 ; P<0.01)$. There was no breed difference in the follicle size at which atresia was first detected or in the overall incidence of atresia, as indicated by similar mean numbers of normal antral follicles, $52.5 \pm 23.8$ and $43 \cdot 1 \pm 16 \cdot 5$ for Romanov and Ile-de-France ewes respectively. The distribution of atretic follicles among Classes 3, 4 and 5 was also the same in the two breeds. The number of corpora lutea of the previous cycle, recorded at the first laparotomy, was variable enough among Romanov ewes (range 2-4) to study the within-breed relationships between ovulation rate and follicular population. There was also no significant correlation between the number of antral follicles per ovary and the ovulation rate of the previous cycle $(r=0.41)$. In fact, there was a general lack of relationship between follicle numbers in a given size class and ovulation rate as demonstrated by correlation values of $0.01,0 \cdot 18,0.34,0.35$ and $0.38(n=8)$ for Classes $1,2,3,4$ and 5 respectively. The measure most closely related to ovulation rate within the Romanov breed was the number of healthy Class 5 follicles at Day 17 of the oestrous cycle $(r=0.66, n=8 ; P<0.05)$.

The pattern of terminal follicular growth is presented in Fig. 3. When the pattern of terminal follicular growth was followed by using ink labelling, a 3-fold difference in the number of follicles growing between Days 13 and 15, was found between breeds (Table 1). There was, however, no breed difference in the number of labelled follicles regressing between Days 13 and 15. Between Days 15 and 17, more follicles went on growing in Romanov than in the Ile-de-France ewes. However, the intensity of selection through atresia, as measured by the ratio of the number of regressing follicles between Days 15 and 17 to the total number of follicles followed between Days 15 and 17 , was similar in ewes of both breeds (Romanov: $48 \cdot 1 \pm 8.4 \%$; Ile-de-France: $50 \cdot 7 \pm 27 \cdot 5 \%$ )

The ink labelling also provided insights on the size of the follicles involved (Table 2) and their growth patterns (Table 3 ). Preovulatory follicles were significantly smaller in Romanov than in Ile-de-France ewes $(6.6 \pm 0.6 \mathrm{~mm}$ versus $8.1 \pm 0.7 \mathrm{~mm} ; n=8 ; P<0.01)$. This was the consequence of the reduced size at Day 15 of the follicles growing from Day 15 to Day 17 (4.9 \pm 1.3 versus $6.4 \pm 1.8 \mathrm{~mm} ; P<0.05$ ) owing to the large number of newly labelled follicles at Day 15 (i.e. follicles not among the three largest of each ovary at Day 13 but still recruited to undergo preovulatory enlargement) in Romanov ewes. However, the size at Day 13 of the largest recruited (i.e.

Table 1. Numerical features of preovulatory enlargement in the different breeds/strains studied

\begin{tabular}{|c|c|c|c|c|c|}
\hline & \multicolumn{5}{|c|}{ Number of follicles: } \\
\hline & $\begin{array}{l}\text { Labelled at the } \\
\text { 1st laparotomy } \\
\text { and growing } \\
\text { until the } 2 \text { nd } \\
\text { laparotomy }\end{array}$ & $\begin{array}{c}\text { Not labelled } \\
\text { initially growing } \\
\text { to be labelled at } \\
\text { the } 2 \text { nd } \\
\text { laparotomy }\end{array}$ & $\begin{array}{l}\text { Total growing } \\
\text { between the first } \\
\text { two laparotomies }\end{array}$ & $\begin{array}{l}\text { Labelled at the } \\
\text { 2nd laparotomy } \\
\text { and growing to } \\
\text { preovulatory size } \\
\text { at the 3rd } \\
\text { laparotomy }\end{array}$ & $\begin{array}{l}\text { Not labelled } \\
\text { previously but } \\
\text { reaching } \\
\text { preovulatory size } \\
\text { at the } 3 \text { rd } \\
\text { laparotomy }\end{array}$ \\
\hline Romanov & $3.0 \pm 0.9$ & $3.6 \pm 1.8$ & $6.6 \pm 1.4$ & $3.4 \pm 0.9$ & 0 \\
\hline $\begin{array}{l}\text { Ile-de-France } \\
F+\text { Booroola }\end{array}$ & $2 \cdot 1 \pm 0.6$ & $0.7 \pm 1 \cdot 1$ & $2 \cdot 8 \pm 1.4$ & $1 \cdot 1 \pm 0.3$ & 0 \\
\hline $\begin{array}{l}\times \text { Romanov } \\
++ \text { Booroola }\end{array}$ & $3 \cdot 6 \pm 0.5$ & $2 \cdot 8 \pm 0.4$ & $6 \cdot 4 \pm 0.5$ & $3.6 \pm 0.5$ & $0.8 \pm 0.3$ \\
\hline$\times$ Romanov & $3.2 \pm 0.9$ & $1.5 \pm 0.6$ & $4.7 \pm 0.7$ & $1.7 \pm 0.8$ & 0 \\
\hline $\begin{array}{l}\text { Finn } \\
\text { Finn } x\end{array}$ & $3 \cdot 2 \pm 0 \cdot 8$ & $1 \cdot 2 \pm 1 \cdot 0$ & $4.4 \pm 1 \cdot 8$ & $3 \cdot 1 \pm 0.9$ & 0 \\
\hline $\begin{array}{l}\text { Blackface } \\
\text { Merino } \times\end{array}$ & $2 \cdot 4 \pm 1 \cdot 0$ & $2 \cdot 1 \pm 1 \cdot 9$ & $4 \cdot 6 \pm 2 \cdot 1$ & $2 \cdot 0 \pm 1 \cdot 1$ & 0 \\
\hline Blackface & $2.5 \pm 0.7$ & $1.9 \pm 1.8$ & $4.4 \pm 1.9$ & $1.6 \pm 0.5$ & 0 \\
\hline
\end{tabular}

Values are mean \pm s.d. 
Table 2. Size of the follicles $(\mathrm{mm})$ involved in preovulatory enlargement at the repeated laparotomies

\begin{tabular}{|c|c|c|c|}
\hline & $\begin{array}{l}\text { Size at the 1st laparotomy of the } \\
\text { follicles labelled and growing until } \\
\text { the 2nd laparotomy }\end{array}$ & $\begin{array}{l}\text { Size at the 2nd laparotomy of the } \\
\text { follicles labelled and reaching } \\
\text { preovulatory size at the 3rd } \\
\text { laparotomy }\end{array}$ & $\begin{array}{c}\text { Preovulatory } \\
\text { size }\end{array}$ \\
\hline Romanov & $3 \cdot 8 \pm 1 \cdot 0$ & $4.9 \pm 1 \cdot 3$ & $6.6 \pm 0.6$ \\
\hline $\begin{array}{l}\text { Ile-de-France } \\
\text { F+ Booroola }\end{array}$ & $3.3 \pm 1.4$ & $6.4 \pm 1.8$ & $8 \cdot 1 \pm 0 \cdot 7$ \\
\hline $\begin{array}{l}\times \text { Romanov } \\
++ \text { Booroola }\end{array}$ & $2 \cdot 7 \pm 0 \cdot 6$ & $4 \cdot 1 \pm 0 \cdot 6$ & $4 \cdot 7 \pm 1 \cdot 0$ \\
\hline$\times$ Romanov & $3 \cdot 9 \pm 1 \cdot 1$ & $6 \cdot 0 \pm 1 \cdot 1$ & $7 \cdot 1 \pm 1 \cdot 0$ \\
\hline $\begin{array}{l}\text { Finn } \\
\text { Finn } \times\end{array}$ & $3.6 \pm 0.7$ & $4 \cdot 5 \pm 1 \cdot 2$ & $5 \cdot 7 \pm 0.6$ \\
\hline $\begin{array}{l}\text { Blackface } \\
\text { Merino } x\end{array}$ & $4 \cdot 0 \pm 1 \cdot 1$ & $4 \cdot 9 \pm 1 \cdot 3$ & $5 \cdot 8 \pm 0 \cdot 5$ \\
\hline Blackface & $3 \cdot 4 \pm 1 \cdot 0$ & $4.4 \pm 1.6$ & $5.9 \pm 0.9$ \\
\hline
\end{tabular}

Values are mean \pm s.d.

Table 3. Follicular growth rates between the repeated laparotomies

\begin{tabular}{|c|c|c|}
\hline & \multicolumn{2}{|c|}{ Growth rate $(\mathrm{mm} /$ day $)$} \\
\hline & $\begin{array}{l}\text { From the 1st to the } \\
\text { 2nd laparotomy }\end{array}$ & $\begin{array}{l}\text { From the } 2 \text { nd to the } \\
\text { 3rd laparotomy }\end{array}$ \\
\hline Romanov & $1.4 \pm 0.4$ & $0.6 \pm 0.3$ \\
\hline Ile-de-France & $1.7 \pm 0.5$ & $0.5 \pm 0.3$ \\
\hline F + Booroola & & \\
\hline $\begin{array}{l}\times \text { Romanov } \\
++ \text { Boorola }\end{array}$ & $0.9 \pm 0 \cdot 2$ & $0.4 \pm 0.5$ \\
\hline$\times$ Romanov & $1.0 \pm 0.4$ & $0.4 \pm 0.4$ \\
\hline Finn & $0.7 \pm 0.3$ & $0.7 \pm 0.6$ \\
\hline Finn $\times$ Blackface & $0.8 \pm 0.4$ & $0.6 \pm 0.7$ \\
\hline Merino $\times$ Blackface & $0.9 \pm 0.4$ & $0.6 \pm 0.5$ \\
\hline
\end{tabular}

growing between Days 13 and 15) follicles was similar between breeds. There was also no significant breed effects on rates on follicular enlargement (Table 3). In both breeds, all of the presumptive preovulatory follicle had been labelled by Day 15 .

\section{Experiment $I I$}

In the two strains $(++$ and $\mathrm{F}+)$ there was no difference in the follicle size at which antrum formation occurred. There was also no significant difference in the mean number of antral follicles per ovary for $F+$ ewes $(40.6 \pm 17.7)$ compared to ++ ewes $(43.2 \pm 15.0)$ (Fig. 1). The distribution of follicles in the size classes was also similar in the two strains, the only feature worthy of note being a significantly higher number of follicles in Class 5 for $F+$ ewes $(4.4 \pm 1 \cdot 1$ versus $2.0 \pm 0.8 ; P<0.01)$. No significant difference was observed between strains in the number of healthy antral follicles $(28 \cdot 6 \pm 16 \cdot 1$ versus $38 \cdot 2 \pm 16 \cdot 1$ for $\mathrm{F}+$ and ++ ewes respectively). However, the occurrence of atresia in the total antral follicle population, expressed as the ratio of the number of atretic follicles to the total number of antral follicles, was significantly higher in ewes carrying the Booroola gene (33.2 $\pm 13.4 \%$ versus $14.5 \pm 9 \cdot 1$ for $\mathrm{F}+$ and ++ ewes respectively; $P<0.02)$. In $\mathrm{F}+$ ewes, in which there was wide variation among ewes in ovulation rate, there was no significant correlation between the total number of antral follicles and ovulation rate $(r=0 \cdot 50$, $n=5)$. Furthermore, with the exception of Class 5 follicles $(r=0.92, n=5 ; P<0.05)$ there was a general lack of correlation between follicular numbers in a given size class and ovulation rate. 
There were differences between strains in the pattern of preovulatory enlargement (Table 1). $\mathrm{F}+$ ewes had more follicles growing between Days 13 and 15. Between Days 15 and 17 the number of follicles continuing to increase in size was greater in $\mathrm{F}+$ than in ++ ewes (Table 2). The loss of follicles through atresia, expressed as the ratio between the number of regressing follicles to the number of follicles followed between Days 15 and 17 , was significantly reduced $(P<0.05)$ in $\mathrm{F}+$ ewes $(43 \pm 7 \%)$ compared to ++ ewes $(60 \pm 12 \%)$. In the two $\mathrm{F}+$ ewes with the highest ovulation rate ( 5 and 6 corpora lutea and 5 and 7 preovulatory follicles respectively), there were 1 or 2 follicles which were not labelled at Day 15, but which were found to be preovulatory at Day 17 .

Associated with the changes in the numerical features of growth, there were differences in the sizes (Table 2) and rates of follicular enlargement (Table 3) of the follicles involved in preovulatory enlargement. The size of the recruited follicles (i.e. growing between Days 13 and 15) was reduced in $\mathrm{F}+$ ewes compared to ++ ewes $(2.7 \pm 0.6 \mathrm{~mm}$ versus $3.9 \pm 1.1 \mathrm{~mm} ; P<0.05)$. As rates of follicular enlargement were similar in the two strains, preovulatory follicles were therefore smaller in $\mathrm{F}+$ than in ++ ewes $(4.7 \pm 1.0 \mathrm{~mm}$ versus $7.1 \pm 1.0 \mathrm{~mm} ; P<0.05)$. They also contained significantly fewer granulosa cells $(F+$ ewes $1605000 \pm 412000, n=17$, versus ++ ewes $3702000 \pm 737000, n=6 ; P<0.01)$. Furthermore in ++ Booroola $\times$ Romanov ewes, preovulatory follicle contained more granulosa cells than in Romanov ewes (3 $702000 \pm 737000$, $n=6$, versus $3026000 \pm 503000, n=12 ; P<0.02$ ). In ++ ewes, all the presumptive preovulatory follicles were labelled at Day 15 compared with $80 \%$ in the $F+$ ewes. At Day 13 , the respective proportions of follicles labelled were 87 and $45 \%$ for ++ and $F+$ ewes.

\section{Experiment $I I I$}

Dissection of all the ovarian follicles $>2 \mathrm{~mm}$ in diameter indicated a mean number of $5 \cdot 1 \pm 1 \cdot 8,7 \cdot 1 \pm 2 \cdot 0$ and $7 \cdot 3 \pm 2 \cdot 4$ follicles per ovary in Finn, Finn $\times$ Blackface and Merino $\times$ Blackface ewes respectively (Fig. 2). The patterns of terminal follicular growth, using ink labelling,

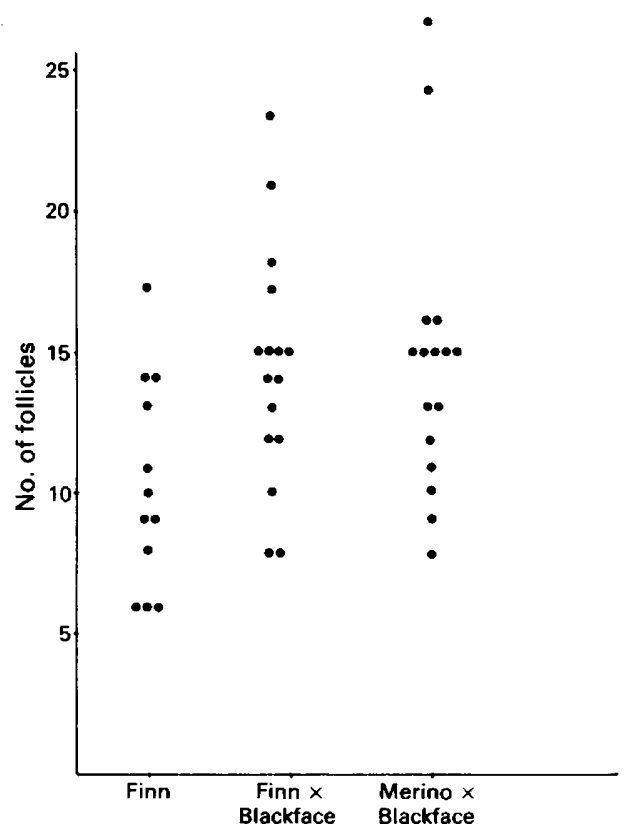

Fig. 2. Total number of follicles $>2 \mathrm{~mm}$ in diameter in Finn, Finn $\times$ Blackface and Merino $\times$ Blackface ewes (Exp. III). 

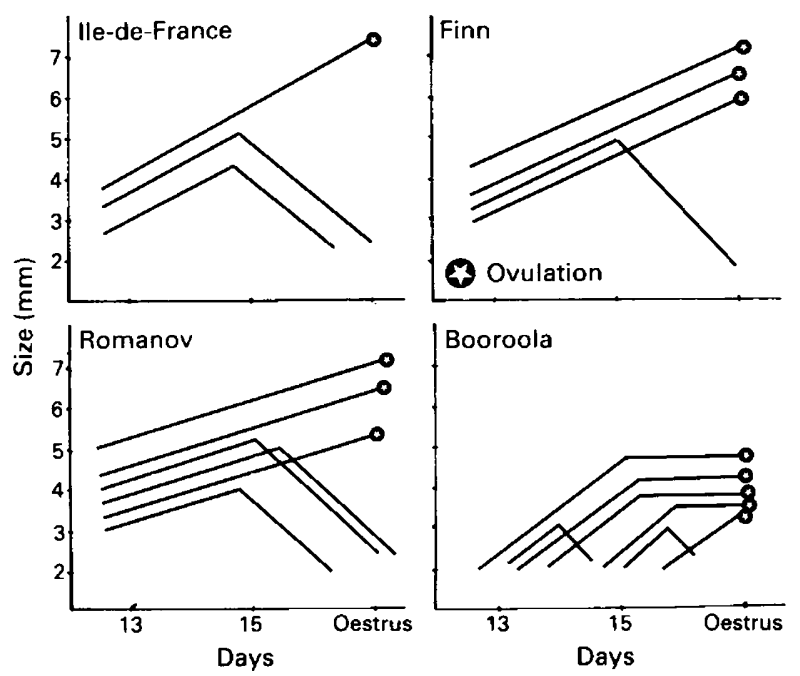

Fig. 3. Schematic pattern of preovulatory enlargement in control (Ile-de-France) and prolific (Romanov, Finn, Booroola) ewes.

are presented in Fig. 3. There was no between-breed difference in the number of follicles growing between Days 9 and 11 (Table 1). However, despite this similarity in the number of follicles recruited, significantly more follicles grew between Days 11 and 12 in Finn than in Finn $x$ Blackface ewes $(R<0.02)$ or Merino $\times$ Blackface ewes $(P<0.01)$. Hence the follicular loss between Days 11 and 12 was significantly higher in the two cross-breds than in the Finnish Landrace ewes $(54 \pm 25 \%, 51 \pm 14 \%$ and $33 \pm 14 \%$ respectively; $P<0.05)$. However, there was no breed effect on the sizes of the follicles involved (Table 2) or their growth rates (Table 3). At Day 9 , significantly more follicles were labelled in Merino $\times$ Blackface $(100 \%)$ than in Finn $\times$ Blackface $(77 \pm 20 \%)$ and Finnish Landrace $(61 \pm 32 \%)$ ewes $(P<0.02$ and $P<0.05$ respectively). At Day 11 all of the preovulatory follicles had been labelled in all three breeds.

\section{Discussion}

These results extend those of a previous study on Booroola ewes (Driancourt et al., 1985a) about ovarian correlates of high ovulation rate to three other prolific breeds or strains.

The first important conclusion is the lack of association between ovulation rate and the overall number of antral follicles available. This conclusion stands both between breeds and also within prolific breeds or strains. This supports previous reports showing a lack of difference in the population of antral follicles in prolific Booroola ewes compared to Merinos of low prolificacy (Driancourt et al., 1985a) despite a 4-fold difference in ovulation rate, in ewes actively immunized against androstenedione and with a $50 \%$ increase in ovulation rate (Driancourt, Jego, Cahill \& Bindon, 1985c), and D'Man ewes in which the very limited difference in follicular population cannot explain the 3-fold superiority over Timhadites (Lahlou Kassi \& Mariana, 1984). The lack of correlation within prolific breed or strain between antral follicle population and ovulation rate also confirms previous data on Booroola ewes (Driancourt et al., 1985a). This relative independence of ovulation rate from the total number of antral follicles available has also clearly been demonstrated when experimental reductions of the overall follicular population were performed. Unilateral ovariectomy does not alter ovulation rate when ewes are ovariectomized far enough from ovulation 
(Land, 1973; Findlay \& Cumming, 1977). Irradiation of prepubertal gilts, despite reducing follicular populations to $10 \%$ that of the controls, did not affect the ovulation rate of these animals at their first cycle (Erickson, 1984).

The results on antral follicle populations obtained from the Romanov ewes in this study are at variance with those of a previous study (Cahill, Mariana \& Mauléon, 1979). A possible reason for this discrepancy could be that in this previous study most of the ewes came from a single family which had an unusually high antral follicle population, although the ovulation rate was in the normal range (M. A. Driancourt \& C. Cornu, unpublished results). This conclusion is further confirmed by data from another experiment in which the antral follicle population was determined in a further 18 Romanov ewes (M. A. Driancourt, unpublished results).

Another feature of interest in the present study is that high ovulation rate was associated with a huge diversity in the size distribution of antral follicles. Similar size distributions were found in twin and single ovulating Ile-de-France (Cahill et al., 1979) and Merino (Driancourt et al., 1985a) ewes as well as in D'Man and Timhadite ewes (Lahlou-Kassi \& Mariana, 1984) and steroidimmunized ewes versus controls (Driancourt et al., 1985c). In contrast, Romanov ewes exhibited an accumulation of follicles in the small and large antral classes while data on Booroola ewes indicated a smaller follicular population in the small antral classes (Driancourt et al., 1985a) but a similar number in the large antral classes (Driancourt et al., 1985a; McNatty et al., 1985). As high ovulation rate is not associated with an overall higher antral follicle population or with a peculiar type of follicular distribution in size classes, and as there is no correlation between the number of follicles $>2 \mathrm{~mm}$ in diameter (i.e. recruitable follicles: see Driancourt \& Cahill, 1984; Tsonis et al., 1984) and the number of follicles in smaller size classes, it might be concluded that research aiming at a better understanding of the mechanisms controlling ovulation rate needs to focus on this population of follicles of $>2 \mathrm{~mm}$ in diameter.

The second important conclusion is that, as indicated by ink-labelling studies, high ovulation rate can be achieved by different mechanisms (Fig. 3). Romanov ewes have a high ovulatory potential because of their large population of recruitable follicles but the intensity of selection through atresia in the late follicular phase is similar to that of the control breed. In contrast Finnish Landrace ewes have a population of recruitable follicles similar to that of the control breeds of lower prolificacy and attain high ovulation rate through a markedly reduced intensity of selection through atresia during the late follicular phase. These mechanisms are different from those previously described for Booroola ewes (Driancourt et al., 1985a), which had a continuous recruitment during the follicular phase, a reduced amount of follicular loss through atresia during the late follicular phase and an ability of fully grown follicles to maintain a steady size for up to 2 days before the preovulatory LH surge. The Booroola $\times$ Romanov ewes with the Booroola gene $(F+)$ had follicular growth features which included a high population of recruitable follicles, similar to the Romanov breed, plus a prolonged recruitment and ability of very small follicles to be recruited, as found previously for Booroola ewes (Driancourt et al., 1985a). This could explain why these F+ ewes had a higher ovulation rate than the usual rate in the parental breeds. However, caution needs to be exercised before the exact mechanism can be specified because these ewes were all sired by a single ram.

Despite the diversity in the strategies used by each of the prolific breeds to generate high ovulation rate, a few features were common to most of the breeds. Firstly, higher prolificacy was associated with reduced preovulatory follicle diameter. This was observed in the Romanov and F+ Booroola $\times$ Romanov ewes and has also been previously described for Finn ewes (Webb \& Gauld, 1984) and for Booroola ewes (Scaramuzzi \& Radford, 1983; Driancourt et al., 1985a; McNatty et al., 1985). Secondly, in all the breeds studied, follicular growth rates measured after ink labelling were similar between prolific and non-prolific breeds, presenting a relatively rapid phase between Days 13 and 15 of the oestrous cycle, followed by a slower rate of growth between Days 15 and 17 . This growth pattern has also been observed in Corriedale ewes (Driancourt \& Cahill, 1984) and 
ewes immunized against androstenedione (Driancourt et al., 1985c). In contrast, in Booroola ewes most of the preovulatory follicles do not grow during the late follicular phase (Driancourt et al., 1985a).

The mechanisms controlling the different patterns of growth described for each prolific breed in this study are not fully known. Previous studies, however, have highlighted possible mechanisms. For Romanov ewes, there are a number of possibilities to explain the greater number of follicles recruited between Days 13 and 15. As there is no difference in FSH concentrations at the time of luteolysis between Romanov and Ile-de-France ewes (Cahill et al., 1981), either a higher follicular sensitivity to FSH or a greater efficiency of the circulating FSH have to be postulated. The first hypothesis is not very likely since an increased follicular sensitivity to FSH would result in changes in follicle numbers and mitotic index of the granulosa cells which have not been observed (Cahill \& Mauléon, 1980). It is therefore possible that FSH from Romanov pituitaries has a higher bioactivity compared to that of non-prolific control sheep. In contrast, Romanov ewes are clearly not deficient in inhibin and/or regulatory proteins since their extent of selection is similar to that of the control breed.

In Finnish Landrace ewes, the main reason for the high ovulation rate is a markedly reduced loss of follicles through atresia. Follicular loss has been suggested as being under the control of FSH and secretion of regulatory proteins (Driancourt, Cahill \& Gibson, 1985b). As FSH concentrations are not raised in Finnish Landrace ewes (Webb \& England, 1982), a reduced ability of the ovaries of these sheep to secrete regulatory proteins might explain the high ovulation rate in this breed.

The different strategies demonstrated in these studies have two important implications. Firstly, they show that there is a very large potential to manipulate terminal follicular growth and thereby increase ovulation rate. Secondly, they suggest that it might be difficult to find early markers of prolificacy which are valid for all breeds.

We thank the E.E.C. for support and the staff of the surgery in A.B.R.O. and I.N.R.A.

\section{References}

Baird, D.T., Ralph, M.M., Seamark, R.F., Amato, F. \& Bindon, B.M. (1982) Pre-ovulatory follicular activity and oestrogen secretion of high (Booroola) and low fecundity Merino ewes. Proc. Aust. Soc. Reprod. Biol. 14, 83, Abstr.

Bindon, B.M. (1984) Reproductive biology of the Booroola Merino sheep. Aust. J. biol. Sci. 37, 163-189.

Cahill, L.P. \& Mauléon, P. (1980) Influence of season, cycle and breed on follicular growth rates in sheep. J. Reprod. Fert. 58, 321-328.

Cahill, L.P., Mariana, J.C. \& Mauléon, P. (1979) Total follicular populations in ewes of high and low ovulation rates. J. Reprod. Fert. 55, 27-36.

Cahill, L.P., Saumande, J., Ravault, J.P., Blanc, M., Thimonier, J. Mariana, J.C. \& Mauléon, P. (1981) Hormonal and follicular relationships in ewes of high and low ovulation rates. J. Reprod. Fert. 62, 141-150.

Cummins, L.J., O'Shea, T., Bindon, B.M., Lee, V.W.K. \& Findlay, J.K. (1983) Ovarian inhibin content and sensitivity to inhibin in Booroola and control strain Merino ewes. J. Reprod. Fert. 67, 1-7.
Davis, G.H., Montgomery, G.W., Allison, A.J. \& Kelly, R.W. (1982) Segregation of a major gene influencing fecundity in progeny of Booroola sheep. N.Z. $J l$ agric. Res. 25, 525-529.

Driancourt, M.A. (1985) Ovarian follicular kinetics in sheep with different prolificacy. M.Sc. thesis, Monash University.

Driancourt, M.A. \& Cahill, L.P. (1984) Preovulatory follicular events in sheep. $J$. Reprod. Fert. 71, 205-211.

Driancourt, M.A. \& Mariana, J.C. (1982) Short and long term effects of $\mathrm{X}$ irradiation on ovarian follicular population in the ewe. Reprod. Nutr. Dévelop. 22, 813823.

Driancourt, M.A., Cahill, L.P. \& Bindon, B.M. (1985a) Ovarian follicular populations and preovulatory enlargement in Booroola and control Merino ewes. $J$. Reprod. Fert. 73, 93-107.

Driancourt, M.A., Cahill, L.P. \& Gibson, W.R. (1985b) Follicular dynamics throughout the oestrous cycle in sheep. A review. Reprod. Nutr. Develop. 25, 1-15.

Driancourt, M.A., Jego, Y., Cahil, L.P. \& Bindon, B.M. 
(1985c) Follicle population dynamics in sheep with different ovulation rate potentials. Livestock Prod. Sci. 13, 21-33.

Erickson, B.H. (1984) Reproductive and genetic effects of continuous prenatal irradiation in the sow. J. Anim. Sci. 59, (suppl. 1), 30, Abstr.

Findlay, J.K. \& Cumming, I.A. (1977) The effect of unilateral ovariectomy on plasma gonadotropin levels, estrus and ovulation rate in sheep. Biol. Reprod. 17, 178-183.

Gougeon, A. (1981) Cinétique de la croissance et de l'involution de follicles ovariens pendant le cycle menstruel chez la femme. D.Sc. thesis, University of Paris VI.

Lahlou Kassi, A. \& Mariana, J.C. (1984) Ovarian follicular growth during the oestrous cycle in two breeds of ewes of different ovulation rate, the D'Man and the Timadhite. J. Reprod. Fert. 72, 301-310.

Land, R.B. (1973) Ovulation rate of Finn Dorset sheep following unilateral ovariectomy or chlorpromazine treatment at different stages of the oestrous cycle. $J$. Reprod. Fert. 33, 99-105.

McNatty, K.P., Henderson, K.M., Lun, S., Heath, D.A., Ball, K., Hudson, N.L., Fannin, J., Gibb, M., Kieboom, L.E. \& Smith, P. (1985) Ovarian activity in Booroola $\times$ Romney ewes which have a major gene influencing their ovulation rate. J. Reprod. Fert. 73, $109-120$.

Pedersen, T. (1970) Follicle kinetics in the ovary of the cyclic mouse. Acta endocr., Copenh. 64, 304-323.
Scaramuzzi, R.J. \& Radford, H.M. (1983) Factors regulating ovulation rate in the ewe. J. Reprod. Fert. 69, 353-367.

Scaramuzzi, R.J., Turnbull, K.E., Downing, J.A. \& Bindon, B.M. (1981) Luteal size and functions in the Booroola Merino. Proc. Aust. Soc. Reprod. Biol. 13, 77 (Abstr.).

Siegel, S. (1956) Non-Parametic Statistics for the Behavioral Sciences. McGraw Hill, New York.

Sokal, R.R. \& Rohlf, F.J. (1969) Biometry. In The Principles and Practice of Statistics in Biological Research. W. F. Freeman, San Francisco.

Tsonis, C.G., Cahill, L.P., Carson, R.S. \& Findlay, J.K. (1984) Identification at the onset of luteolysis of follicles capable of ovulation in the ewe. J. Reprod. Fert. 70, 609-614.

Webb, R. \& England, B.G. (1982) Identification of the ovulatory follicle in the ewe: associated changes in follicle size, thecal and granulosa cell luteinizing hormone receptors, antral fluid steroids and circulating hormones during the preovulatory period. Endocrinology 110, 873-881.

Webb, R. \& Gauld, I.K. (1984) Folliculogenesis in sheep: control of ovulation rate. In Genetics of Reproduction in Sheep, pp. 261-275. Eds R. B. Land \& D. W. Robinson. Butterworths, London.

Received 10 March 1986 